\title{
A history of the gardens of the Royal College of Physicians of London
}

\author{
Arthur Hollman
}

\begin{abstract}
The Royal College of Physicians of London (RCP) was founded in the City of London in 1518 and at that time many of the royal, religious and lay residences had gardens. The gardens were used, among other things, to grow fruit trees, herbs for the kitchen and for strewing on the floor, and for leisure, with lawns, bowling and flowers. So it would have been natural for the RCP Fellows to wish to have a garden of their own. This was not possible until the College moved into its second and third homes in the City in 1614 and 1674 and good street plans of these sites, and of their gardens, have now become available, though we lack any details of the planting. The fourth home in Pall Mall East in 1815 was landlocked. Therefore when the fifth (and current) home in Regent's Park was opened in 1964 it was splendid to have a large garden, carefully designed, planted and recorded. In 2004 a wonderful transformation took place when the College created a modern physic garden showing the development of medicinal plants through the ages and in many parts of the world.
\end{abstract}

KEY WORDS: Amen Corner, City of London, herb gardens, John Gerard, medicinal plants, physic gardens, Royal College of Physicians of London, Wolfson Foundation

The Royal College of Physicians of London (RCP) was founded in 1518 by Thomas Linacre who gave his home, the Stone House in Knightrider Street in the City of London, to the new institution. In those days most houses in the city had a garden, but Linacre's house was not large and probably the garden proved too small. Whatever the reason, it is known for certain that later on the RCP sought a garden elsewhere, because they asked one of their Fellows, Dr Sackford, if they might purchase his land. The Annals record the transaction on 12 July 1587 :

The following decision was reached regarding the purchase of a garden from Dr Sackford, since his price seemed too high; some members of the College were to visit Dr Sackford and offer him an annual rent of forty English marks which, if he accepted, they were to transact the whole business with him. But if he demanded a higher sum then we were to withdraw and leave the business to others. ${ }^{1}$

One mark in 1587 is equivalent to $\mathfrak{£ 9 7 . 2 7}$ in modern day currency and so the RCP was offering the astonishing sum at today's prices of $\mathfrak{E} 3,890$ a year.

Arthur Hollman, Emeritus Consultant Cardiologist, University College Hospital, London; Curator of the herb garden of the Worshipful Company of Barbers

\author{
John Gerard, herbarist and surgeon, \\ is asked to help
}

There is no record of the outcome of that affair, but clearly it did not go through because in that same year the RCP approached John Gerard for assistance. Gerard (1545-1612) was a surgeon, a liveryman of the Company of Barber-Surgeons. He was also an expert plantsman, or horticulturist as we would say today, then known as a herbarist (not herbalist), and he was the superintendent of Lord Burghley's gardens at Cecil House, in The Strand, and at Theobalds House, in Hertfordshire, where the gardens were reputed to be as fine as those at Hampton Court. Gerard was an ideal person for the RCP to approach and the Annals of 6 October 1587 state, 'John Gerard, surgeon, promised that he would look after the College garden, and agreed to keep it stocked with all the rarer plants for a reasonable charge.' Unfortunately there is no evidence that such a garden was ever planted, but there is an alternative possibility.

Gerard had a garden of his own which was richly stocked with plants, on the south side of Holborn. Indeed, in 1596 he published the first ever catalogue of plants growing in one garden with a description of no less than 1,030 species in what he called, The little plot of myne owne especiall care and husbandry. It is possible that Gerard set aside a portion of this garden for the College's use but again there is no written evidence for this. In passing it is worth noting that in 1597 Gerard wrote his famous book The herball or general historie of plantes. ${ }^{3}$ So by 1614 when the RCP left the Stone House they still had no garden of their own.

\section{The College moves to a new home at Amen Corner near St Paul's Cathedral}

For their second home the RCP took a 40-year lease from the Dean and Chapter of St Paul's Cathedral of 'that great Messuage known as the Physicians College situate lying and being at the west end of Paternoster Row called Amen Corner'. ${ }^{4}$ The lease mentions a garden and we are fortunate to have a clear description of it in William Munk's A short account of the College. ${ }^{5} \mathrm{He}$ writes, 'the College garden, of an irregular form, extended as far as the Old Bailey to the west, and reached to the church of St Martin Ludgate, towards the south'. In a recently discovered map of London of 1558, the Copperplate Map, one can see the College building with the garden clearly identified (Fig 1). Although described as being at Amen Corner, Stowe's survey of London states that the RCP was in Amen Lane which would be to the west of Amen Corner. ${ }^{6}$ The entrance to the College was 


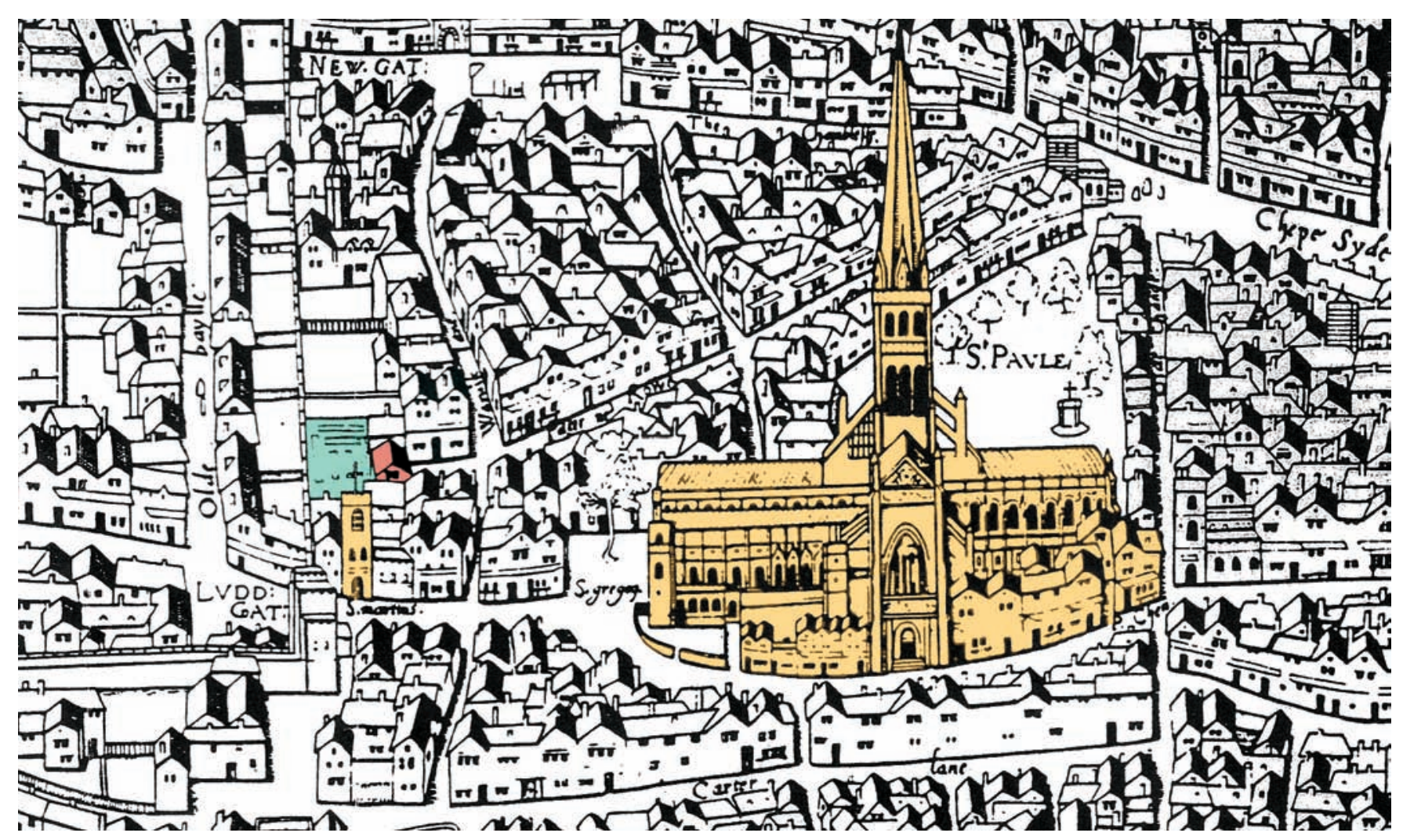

Fig 1. Street plan on the Copperplate Map of 1558 showing the area around St Paul's Cathedral where the second home of the Royal College of Physicians was located. College building is shaded red, the garden is green and St Martin's Church is yellow. (C) Museum of London.

probably from Amen Corner with the plot facing onto the lane (Fig 2).

In Farre's history of the RCP there is a plan of the College in 1649 showing the garden (Fig 3). ${ }^{7}$ It was quite large being 66 feet wide and 100 feet long with its west border against the High Walk in front of the City Wall, and a garden entrance from the main building is clearly labelled. Dr Charles Newman, a former Harveian Librarian, told me that there was a recess in the west wall for gardeners' tools. The official history of the College is wrong to suggest that there was not a physic garden at Amen Corner, though it does add that the RCP did not have the money either to pay a gardener or to stock a garden.

It is puzzling to read that in 1631 Dr Henry Atkins, a former President of the RCP, proposed sending a petition to King Charles 1 for help in providing the College with a garden. The King referred the matter to the Privy Council who sent it back to the College which appointed a committee. But Dr Atkins became ill and the proposal went no further. The King had been approached because his Privy Council often sought the advice of the College on matters such as the plague and it was hoped to get a favour in return. ${ }^{8}$ However, on 4 July 1651 at an extraordinary Comitia the President, Dr Prujean, said to the Fellows, 'If I can procure one that will build us a library, and a repository for simples and rarities... will you assent to have it done or no.' The term 'simple' was used to denote a remedy created from only one species of plant, as opposed to a compound. The RCP's second home came to house the Musaeum Harveianum, a private collection of books donated to the College by William Harvey.

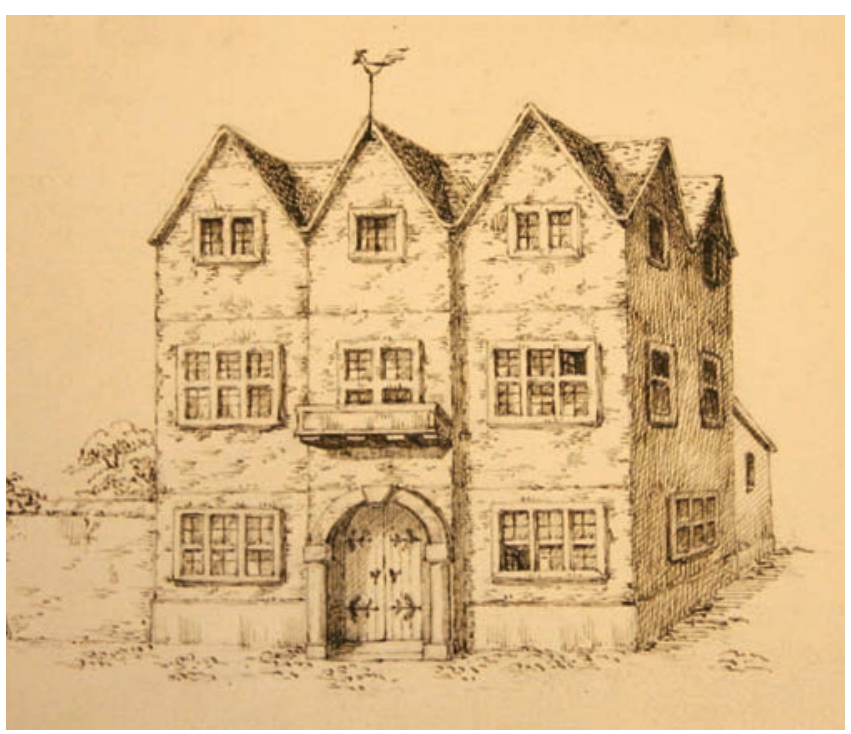

Fig 2. The College building at Amen Corner, no date given. It is likely that this picture was created from a written description and not made from direct observation of the building. ${ }^{7}$ 


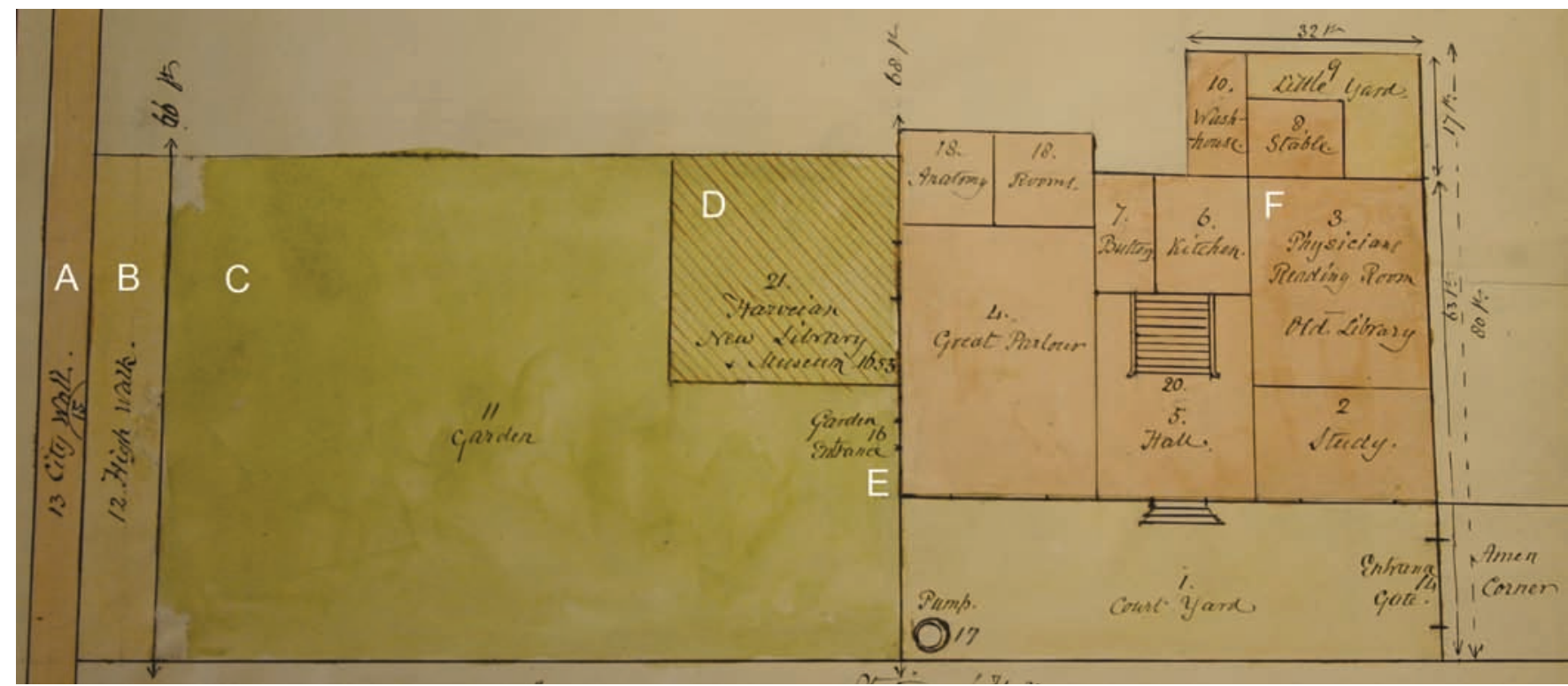

Fig 3. The ground plan in 1653 of the second home of the College at Amen Corner. (A) City Wall (B) High Walk (C) garden (D) Harveian Library and Museum (E) garden entrance $(F)$ reading room. ${ }^{7}$

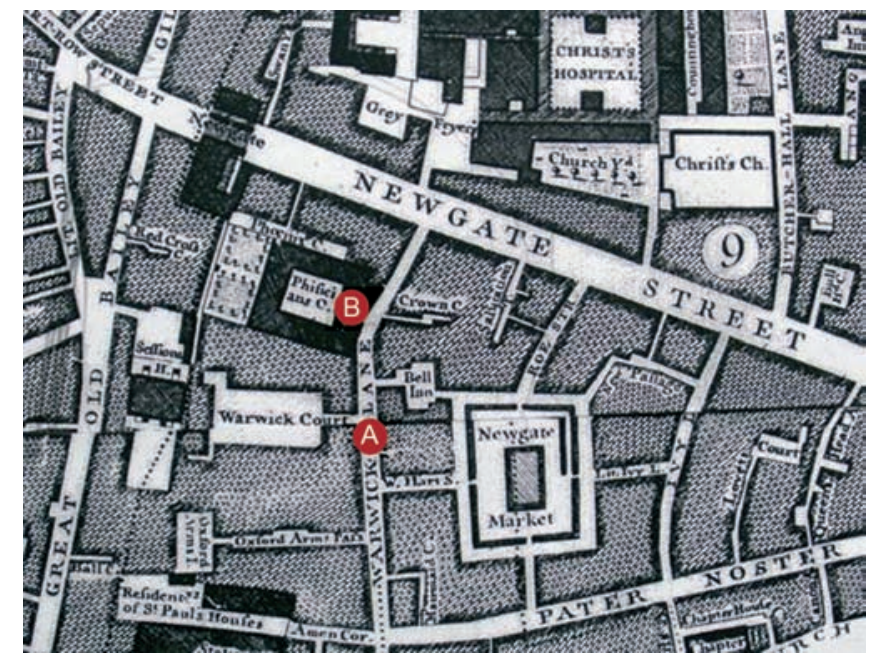

Fig 4. Street plan of John Rocque's map of 1746 showing the third home of the College in Warwick Lane with the garden to the left. (A) Warwick Lane, (B) College.

(C) City of London: London Metropolitan Archives.

Harvey's great bequest led to the creation of a museum with a library in 1653 but it is doubtful whether Dr Prujean intended that the 'simples' would be grown at the College. Regardless, on 6 September 1666, the RCP's home of 52 years was destroyed in the Great Fire of London.

\section{In 1674 the College moves to its third home in the City}

A new College building was built to the north of St Paul's Cathedral in Warwick Lane. It was designed by Mr Robert Hooke and was opened in 1674. Again the College history is vague as to whether or not there was a garden. But an excellent map of the City, made by John Rocque in 1746, shows the garden very clearly, with a parterre containing what look like two planted areas enclosed by box hedges (Fig 4). Other evidence tells us that the garden was 118 feet wide, 70 feet long on the north side and 64 feet wide on the south. ${ }^{10}$

In 1769 the City of London decided to rebuild the Newgate Gaol, which was to the west of the College, and extend it onto the College site. The RCP objected on the grounds that contagion from the prison would spread to the College and also that the City would offer only $\mathfrak{E} 600$ in compensation for the land whereas the college wanted $£ 1,000$. Unfortunately, the City owned the freehold and there was no option but to lose part of the garden. ${ }^{11}$

\section{A new home in Westminster}

By the end of the 18th century the residential centre of London had moved to the west, to Bloomsbury and Soho, and few Fellows still lived in the City. The RCP followed suit and in 1825 its fourth home was built in Pall Mall East on the west side of Trafalgar Square. This was a landlocked site and there was no garden apart perhaps from a few window boxes.

\section{The College's fifth home in Regent's Park}

The RCP remained in Trafalgar Square for 139 years until the fifth and present house in Regent's Park opened in 1964. It was such an imaginative idea on the part of the then president, Sir Robert (later Lord) Platt, to obtain this site, one which was not hemmed in by nearby buildings and therefore gave great scope to the architect, Sir Denys Lasdun. Lasdun originally planned to have the long axis of the building parallel to the park but then 
decided to swing it through 90 degrees. ${ }^{12}$ One effect of this decision was to create an open space to the south of the building where a garden could be established, facing the fine facade of the houses in St Andrews Place. This proved possible through the great generosity of Dr WSC Copeman.

Copeman gave the RCP enough money to create and plant a garden in memory of his father Dr Sydney Monckton Copeman: a splendid example of filial devotion. At that time there was a five foot wall across the southern boundary of the garden, fronted by a long flower border. A firm of nurserymen was engaged and planting began in 1965. Copeman enforced no conditions for the garden except that there should be a willow tree and a castor oil plant. The former because salicylates were used in his specialty of rheumatology, and the latter because he believed that the public associated doctors with castor oil - a comment coming from a doctor born in 1900! In the event it was the hardy false castor oil plant Fatsia japonica that was used and which remains today against the offices on the east side of the plot.

An important decision was made to commemorate Hippocrates, the father of medicine who taught underneath a plane tree on the island of Cos, by planting two Oriental plane trees Platanus orientalis. The tree you see today came originally from seeds taken from an ancient plane tree on Cos by the famous Montreal neurosurgeon, Dr Wilder Penfield. Those seeds produced a tree at the Rockefeller Institute in New York from where cuttings were taken to Kew Gardens by Mrs Detler Bronk, wife of the president of the institute. Kew raised plants from them and Sir Robert Platt, acting on information given to him by Sir Henry Dale, obtained a plant for the College garden from Sir George Taylor, the director of Kew. In 1970 the Treasurer, Dr Dick Bomford wrote 'both trees are growing alarmingly fast but our tree expert says they can be kept down to a reasonable size by suitable pruning. ${ }^{13}$

After some 10 years or so the nursery firm withdrew their contract and the garden was neglected. By then I had become the College's representative at the Chelsea Physic Garden and the poor state of the grounds being obvious I offered to look after it. Working nearby at University College Hospital made it easy to visit on the way home and I became the unofficial gardener in 1977 until I retired from the NHS in 1987. By this time the second plane tree was already overshadowing the administrative block on the east and was clearly going to be much too big for the site. I suggested to the Bedell, $\mathrm{Mr}$ Kirkpatrick, that the tree should be removed, and being an exRegimental Sergeant Major he soon had it done. Nowadays with conservation to the fore this would have been impossible. This tree came from the Chelsea Physic Garden where a tree had been grown from a cutting taken at Cos in 1951 by Dr Loverdos. Had that second tree remained, the garden today would be completely overshadowed by two large trees. The existing tree has never had major pruning, and plane trees do get blown down, but maybe the Hippocratic provenance will save it. Personally I wish it had never been put in as it is far too big for the site.

\section{A new layout for the garden in 1978}

After a few years in charge of the garden and with the support of the President, Sir Douglas Black and his wife, I was able to implement a new planting regime. In 1979 I published a catalogue of the garden. ${ }^{14}$ My main idea was to link the garden with the College, with British medicine and with the practice of medicine. There were nine main categories and each one is followed by a small selection of the plants within it:

- the College arms: pomegranate, Punica granatum, planted by the president in 1977 to mark the Silver Jubilee of Queen Elizabeth II

- men and women who have served the College: Acanthus spinosus for Sir Denys Lasdun, the Acanthus motif is on Corinthian capitals; Senecio maritima for Dame Sheila Sherlock, the first woman senior censor and a renowned hepatologist (Senecio is a liver poison)

- kindred royal colleges and societies: the Worshipful Society of Apothecaries: the Apothecaries rose Rosa gallica officinalis; the RCP Australasia: Hebe albicans from New Zealand and Grevillea rosmarinifolius from Australia

- plants named for British doctors: John Fothergill (1712-80) Fothergilla monticola; Clarke Abel (1780-1826) Abelia chinensis, Abel was surgeon to the British embassy in Peking; Richard Mead (1673-1754) Dodecatheon meadii, Mead was an owner of the Gold Headed Cane and persuaded Thomas Guy to found a hospital; Augustine Henry (1857-1930) Lilium henryi, a Belfast graduate Henry became a great plant collector in China

- commemorative plants: Asklepios (Aesculapias), son of Apollo, is the patron saint of medicine: Asclepias incarnate, a member of the Milkweed family. Stephen Hales (1677-1761) Halesia carolina the Snowdrop Tree. Hales was the first to measure blood pressure and also the pressures exerted by plants

- plants which yield recognised medicines: these included Mandragora officinarum, Mandrake which contains hyoscine, and Digitalis lanata which yields digoxin. There were several others such as willow, liquorice and opium poppy

- plants named after diseases: Lobelia syphilitica said to have been used by the native North Americans

- culinary herbs: sage, lettuce, chives and mint

- plants to please the eye: the 20 or so plants in this category include the Witch Hazel Shrub Hamamelis Mollis 'Pallida', now over 30 years old.

\section{The newly created College garden}

In 2004 the College Treasurer had the farsighted idea that a substantially new medicinal garden should be developed and the experienced horticulturist Mark Griffiths was approached to do this. It proved to be a very exciting new development, in effect a 
modern physic garden, and nearly 1,000 species were sourced and planted between 2005 and 2008. It was possible only with very generous grants from the Wolfson Foundation. It is good to know that Lord Wolfson, an Honorary Fellow and Friend of the College, takes a very active interest in the garden. It contains species and cultivars from across the globe to reflect different native traditions of medicine and to demonstrate plants of established, and more recently determined, clinical significance. It may be the most diverse garden of medicinal plants to be created in Britain since the 17th century. It is now under the direction of the Garden Fellow, Dr Henry Oakeley. ${ }^{15}$ The head gardener, Jane Knowles, has designed and planted eight new plots in front of the houses in St Andrews Place which contain plants used in medicine and published in the College's 1618 Pharmacopaeia Londinensis.

\section{Acknowledgements}

My warm thanks go to Pamela Forde, College Archivist, for much appreciated help in sourcing and referencing original documents. I am indebted to Sir Richard Thompson, the College Treasurer, for his valued encouragement and support, and to Andrew Hilson, the Harveian Librarian, for his very helpful advice. John Fisher of the Guildhall Library was of great assistance with maps of London.

\section{References}

1 Annals of the Royal College of Physicians of London. Folio 60b, 12 July 1587, MS 4143, p 47.
2 Annals of the Royal College of Physicians of London. Folio 61b, 6 October 1587, MS 4143, p 48.

3 Hollman A. John Gerard. In: Burns I (ed), Notable barber surgeons. London: Farrand Press, 2008.

4 Indenture of Bargain and Sale, 28 September 1649, A2, legal documents catalogue, p 5 (heritage collections of the Royal College of Physicians of London).

5 Munk W. A short account of the College. The roll of the Royal College of Physicians of London. 1878:324.

6 Harben HA. A dictionary of London. London: Herbert Jenkins Ltd, 1958:20, 21.

7 Farre FJ. Scrapbook of drawings, maps, plans and photographs to illustrate his history of the College (1883). Archives of the Royal College of Physicians of London. Farre's Scrapbook, MS 2245.

8 Annals of the Royal College of Physicians of London. Vol IV (1647-82).

9 Clark G. A history of the Royal College of Physicians of London. Oxford: Clarendon Press, 1964:256.

10 Legal documents of the Royal College of Physicians of London. W22, Envelope 273.

11 Legal documents of the Royal College of Physicians of London. W21, Envelope 267.

12 RIBA trustees medal 1992. RIBA journal 1993;100:22-6.

13 Bomford R. Treasurers Column. College Commentary 1970;4:47-8.

14 Hollman A. The garden of the Royal College of Physicians of London. London: RCP, 1979.

15 Oakeley H. A walk around the College garden. College Commentary 2007:32-3.

Address for correspondence: Dr A Hollman, Sea Bank, Chick Hill, Pett, East Sussex TN35 4EQ.

Email: arthur@hollman.co.uk 